\title{
Impact Of Inter-Professional Education On Nursing Student Outcomes In The Online Environment
}

\author{
Suzanne J. Crouch, Chamberlain College of Nursing, USA \\ Laura Fillmore, Chamberlain College of Nursing, USA \\ Linda M. Fly, Chamberlain College of Nursing, USA \\ Eme Ukot, Chamberlain College of Nursing, USA
}

\begin{abstract}
The implementation and integration of inter-professional education (IPE) into a curriculum is supported by the National Council of State Boards of Nursing (NCSBN), the Inter-professional Education Collaborative (IPEC), and the Institute of Medicine's (IOM) Future of Nursing report. While there is support for implementation, there is a lack of data and guidelines which to follow currently. The purpose of this nursing research study was to investigate the impact of interprofessional collaboration on nursing student outcomes in the online environment. A co-teaching model was implemented within an online environment to provide inter-professionally lead nursing sciences courses to nursing students in a baccalaureate program. In the four sessions following the implementation of interdisciplinary collaborative teaching, 605 students completed the courses with 179 submitting the end of course survey. Results indicated that the overall student satisfaction rating with the pathophysiology online course was significant at $p<0.05$ following the implementation of inter-professional teaching methodology. Prior to implementation of collaborative teaching, the total enrollment in pathophysiology was 194. After the institution of collaborative teaching, the total student enrollment was 605. This reflected a significant increase in student enrollment of $311 \%$. Today, the complex healthcare delivery system necessitates a shift from traditional education to an inter-professional collaborative teaching model that generates knowledge from interaction with a variety of educators from a variety of disciplines (Hean, Craddock, \& Hammick, 2012). Nursing curricula is needed which fosters both an interprofessional learning of shared knowledge and the discipline-specific learning essential for professional practice.
\end{abstract}

Keywords: Inter-professional Education; Nursing Student Outcomes

\section{INTRODUCTION}

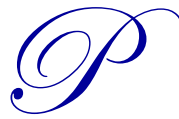

rofessional healthcare practice includes work with inter-professional teams. Preparation for future practice is best developed by interaction and integration of teamwork during the student phase. The challenges of integrating inter-professional education are similar to the professional team challenges. Limitations to full integration are professional standards, control, location, and, traditions. Without commonly available models, “...faculty who provide these experiences often do so as pioneers" (Alberto \& Herth, 2009, p. 9). These limitations create questions and issues that can sideline the efforts to integrated educational learning environments. While the challenges for implementation are many, the benefits are to expose students to an interprofessional lens early in their educational preparation.

The healthcare environment is complex and demanding, and new practitioners are required to step into practice roles and perform at high levels as they transition from school to practice. Many new graduates are not prepared for the professional demands of the healthcare environment as well as the collaboration with the healthcare 
team. The effort to improve the transition period and improve readiness for transition must begin in the educational preparation.

The complex care required in acute care settings is now occurring in the outpatient setting as care continuous to move from traditional locations such as hospitals and is occurring in the community, clinics, faithbased organizations, and also homes. Nursing students at the baccalaureate level may be placed into position of leadership and care coordination early in their practice. Communication with the healthcare team is a necessary component of patient centered care.

Alberto and Herth (2009) discuss the importance of improved healthcare outcomes globally which is supported when inter-professional education crosses the boundaries of professions and locations. The mission and vision of the college in this study is consistent with the goal of transformational health worldwide. Initiatives are occurring in multiple countries and organizations to improve, encourage, and support collaborative teams in education and practice.

\section{BACKGROUND}

The nursing curriculum provides opportunities for students to interact with other nurses in classroom and clinical settings. These interactions become the basis for professional modeling and assimilation into nursing practice. The incorporation of multi-disciplines into nursing instruction allows for interaction and professional modeling with other healthcare disciplines. The collaboration also allows students to interact, discuss, and learn from Healthcare providers with a different patient perspective. The inter-professional interaction has been encouraged in simulation labs, with a variety of inter-professional students and teachers. Another area of integration is in the courses often called the nursing science courses or nonclinical courses. The NCSBN has made recommendations to use inter-professional teaching models in the nursing sciences.

The benefits of inter-professional education collaboration according to Dyer (2003) allow students the opportunity to learn from the "...knowledge, skills, and responsibilities across traditional disciplinary boundaries in assessment and service planning" (p. 187). The implementation of inter-professional learning models is also to enhance the learning environment and therefore the student learning experience and student outcomes. Interprofessional collaboration in the educational process allows for an intentional, adaptive process to respond and improve the students experience outside of the boundaries of just one faculty, but with the collaborative team (Alberto \& Herth, 2009).

The development of an inter-professional model requires clarification of the roles, limits, and design of a co-faculty course in materials and facilitation methods. "Little attention has been paid in the literature defining continuing IPE curricula... and establishing best practices in IPE..." (Silver \& Leslie, 2009, p. 173). The interprofessional team has to clarify the vision and purpose of the collaboration to position the partnership for success (Alberto \& Herth, 2009). The design is required prior to implementation to ensure all regulatory and accreditation standards are met. The implementation of a co-faculty model necessitates prelaunch planning and meetings to ensure both faculty know the role and responsibilities. The proper preparation of faculty prior to teaching, results in student's own understand of the design, which limits frustration and confusion.

Following the launch of the inter-professional course is the evaluation and feedback which is needed for course assessment, course improvement, and evaluation of roles and responsibilities. The evaluation is important to validate if the model is impacting student outcomes, either positively or negatively. This study investigated the impact of inter-professional collaboration in nursing science courses delivered in an online modality to prelicensure nursing students.

\section{PURPOSE}

According to Dyer (2003), the inter-professional educational model is one in which "two faculty members teach aspects of the course relative to their expertise" (p. 188). The American Association of Colleges of Nursing has integrated inter-professional collaboration expectations into its Essentials for baccalaureate (2008) master's 
(2011) and doctoral education for advanced practice (2006). The purpose of this nursing research study was to investigate the impact of inter-professional collaboration on baccalaureate nursing student outcomes in the online environment.

\section{THEORETICAL FRAMEWORK}

Inter-professional education, as defined by the World Health Organization (WHO, 2010), occurs when professionals from multiple disciplines learn while engaging with each other through effective collaboration. Published empirical evidence does not reference any one particular theoretical framework for the inter-professional educational model (Barr et al., 2005). Social constructivism supports the philosophy that the learning, which takes place within inter-professional education (IPE), cannot be achieved in isolation. Atherton (2009) suggests that social interactions influence the learner's understanding of concepts and the meanings he ascribes. Atherton believes that learners are more actively involved in the learning process with the presence of a collaborative facilitator as found in inter-professional education. A collaborative teaching model allows multiple educators to support and facilitate the students' learning while building upon their own existing knowledge based and acquiring new information (Hean, Craddock \& O’Hallran, 2009).

Vygotsky's (1978) theory of socio-cultural learning provides the foundation for social constructivism. Vygotsky describes a level of academic development, more accurately called the zone of proximal development (ZPD), which can be enhanced through the assistance of an inter-professional educator as compared to that of an independent learning model. Within a collaborative inter-professional education model, the co-faculty role is viewed as the facilitating variable that can accelerate learning across the ZPD. Inter-professional education correlates with constructivism theory since the student learns through a dynamic process with multiple facilitators thereby allowing learners to construct new ideas based upon both past and current levels of knowledge (Brandon \& All, 2010). Therefore, constructivism theory serves as the foundational theoretical underpinnings for this study.

\section{METHODOLOGY}

The Chamberlain College of Nursing $(\mathrm{CCN})$ prelicensure online team created and initiated an innovative inter-professional collaborative teaching methodology which was approved by the $\mathrm{CCN}$ undergraduate curriculum committee. Inter-professional education utilizes a variety of disciplines including nursing faculty, physicians, pharmacists, and chiropractic physicians to provide educational offerings to students. Educators work as members of a multidisciplinary team, they learn from each other, take responsibility and ownership, and strive for continuous improvements using evidence-based practice to drive decisions (Devry, 2013).

The online nursing program at Chamberlain College of Nursing uses an inter-professional team approach for teaching nursing science courses such as Pharmacology and Pathophysiology. Two faculty members are assigned to each course: a nursing faculty with licensure in multiple states and a healthcare professional such as a physician, chiropractic physician or a pharmacist. The class workload is divided between both faculty members. The nursing faculty is responsible for examinations, and incorporating a professional nursing perspective to the discussions. The co-faculty is responsible for the discussion posts, content questions and the grading of all classroom assignments. Orientation of co-faculty is conducted by the faculty manager and the nursing faculty team member. Team meetings are held at scheduled times for all faculty.

\section{DESIGN}

A quantitative descriptive and experimental correlational design formed the basis for this study. This research design examined relationships among variables, described the variables, and determined a cause-and-effect relationship between variables. Data collection took place over a 12 month period from July 1, 2011 to June 30, 2012. The convenience sample included 838 nursing students, of which 799 completed both nursing science courses. All students were enrolled in a sequence of two Pathophysiology classes as a requirement of a prelicensure baccalaureate degree program. IRB approval was obtained for this study. 


\section{PARTICIPANTS}

The convenience sample included 838 nursing students, of which 799 completed both online nursing science courses. The number of students completing the pathophysiology courses in the two sessions prior to the implementation of interdisciplinary collaborative teaching equaled 194 students. In the four sessions following the implementation of an interdisciplinary collaborative teaching methodology, 605 students completed the courses. The participants voluntarily completed an end of course survey available during the final two-week of the enrolled online pathophysiology course. The number of students completing the courses in the two sessions prior to the implementation of interdisciplinary collaborative teaching equaled 194 students with 74 completing the end of course survey. In the four sessions following the implementation of interdisciplinary collaborative teaching, 605 students completed the courses with 179 submitting the end of course survey (See Table 1).

Table 1. Students Response Rate

Pathophysiology NR281

\begin{tabular}{lcccccc}
\hline Students & $\begin{array}{c}\text { Returned } \\
\text { Surveys }\end{array}$ & Return Rate & $\begin{array}{c}\text { Course } \\
\text { Evaluation } \\
\text { Mean }\end{array}$ & $\begin{array}{c}\text { Faculty } \\
\text { Evaluation } \\
\text { Mean }\end{array}$ & $\begin{array}{c}\text { Environment } \\
\text { Evaluation Mean }\end{array}$ \\
\hline 11-Jul & 110 & 43 & $39 \%$ & 2.77 & 3.19 & 2.65 \\
11-Nov & 116 & 35 & $30 \%$ & 3.38 & 3.36 & 3.45 \\
12-Mar & 168 & 67 & $39 \%$ & 3.59 & 3.63 & 3.56 \\
\hline
\end{tabular}

\section{DATA ANALYSIS}

A quantitative descriptive and an experimental correlational design formed the basis for the research design of this study. In this study, a survey using a Likert-styled questionnaire with open-ended questions was utilized. The Statistical Package for Social Sciences (SPSS) was used for data analysis. Descriptive and correlational analyses were conducted on the data collected. All data was stored in a computerized database with access restricted to the researchers of the study. The t-test and Chi square test were used to assess the correlation between the student evaluations prior to and following implementation of inter-professional collaboration. Levene's tests for equality of variances were conducted to assess the internal consistency of the measurement scales and all data (Table 2).

Table 2. Quantitative Data Analysis

Student evaluation questions used for this analysis are listed below:

\begin{tabular}{|c|c|c|c|c|}
\hline \multirow{2}{*}{ Questions } & \multicolumn{4}{|c|}{ Scale } \\
\hline & 1 & 2 & 3 & 4 \\
\hline $\begin{array}{l}\text { What is your overall satisfaction with this course? - Course } \\
\text { overall satisfaction (OS) }\end{array}$ & \multirow{3}{*}{$\begin{array}{c}=\text { Not at all } \\
\text { satisfied }\end{array}$} & \multirow{3}{*}{$=$ Dissatisfied } & \multirow{3}{*}{$=$ Satisfied } & \multirow{3}{*}{$\begin{aligned}= & \text { Extremely } \\
& \text { satisfied }\end{aligned}$} \\
\hline $\begin{array}{l}\text { What is your overall satisfaction with this instructor? - } \\
\text { Instructor overall satisfaction (OS) }\end{array}$ & & & & \\
\hline $\begin{array}{l}\text { What is your overall satisfaction with your experience with } \\
\text { the online classroom for this course? - Environment overall } \\
\text { satisfaction (OS) }\end{array}$ & & & & \\
\hline
\end{tabular}

Student responses were categorized into two groups, Pre (prior to the implementation of the interprofessional teaching model and Post (following the implementation of the inter-professional teaching methodology), as defined below (Table 3).

Pre - All students who took the first course in pathophysiology prior to implementation of the interprofessional teaching model (Summer, 2011 A). Post - All students who took the first course in pathophysiology after the implementation of inter-professional teaching model (Fall 2011 A and Spring 2012 A). 
Table 3. Analysis Report for student responses categorized into pre and post groups

\begin{tabular}{l|c|c|c}
\hline \multicolumn{3}{c}{ Means } \\
\hline \multicolumn{1}{c|}{ Groups } & Mean of CourseOS & Mean of InstructorOS & Mean of EnvironmentOS \\
\hline Pre & 2.77 & 3.19 & 2.65 \\
Post & 3.23 & 3.35 & 3.15 \\
\hline
\end{tabular}

In depth Analysis: T-test was done to examine if the means are significantly different, results as below (Table 4, Table 5, Table 6, Table 7, Table 8, \& Table 9).

Table 4. T-test for Course Overall Satisfaction (OS)

\begin{tabular}{|c|c|c|c|c|c|}
\hline \multicolumn{6}{|c|}{ Group Statistics } \\
\hline & Group & $\mathbf{N}$ & Mean & Std. Deviation & Std. Error Mean \\
\hline \multirow{2}{*}{ CourseOS } & Pre & 43 & 2.767 & .7819 & .1192 \\
\hline & Post & 102 & 3.225 & .7299 & .0723 \\
\hline
\end{tabular}

Table 5. Independent Samples Test for Course Overall Satisfaction

\begin{tabular}{|c|c|c|c|c|c|c|c|c|c|}
\hline \multirow[b]{2}{*}{ CourseOS } & \multicolumn{2}{|c|}{\begin{tabular}{|c|} 
Levene's Test for \\
Equality of Variances \\
\end{tabular}} & \multicolumn{7}{|c|}{ t-test for Equality of Means } \\
\hline & $\mathbf{F}$ & Sig. & $\mathbf{t}$ & df & Sig. (2-tail) & $\begin{array}{c}\text { Mean } \\
\text { Difference }\end{array}$ & $\begin{array}{l}\text { Std. Error } \\
\text { Difference }\end{array}$ & $\begin{array}{r}95 \% \mathrm{C} \\
\text { Interv } \\
\text { Diff }\end{array}$ & $\begin{array}{l}\text { fidence } \\
\text { of the } \\
\text { ence }\end{array}$ \\
\hline \multirow{2}{*}{$\begin{array}{l}\text { Equal variances } \\
\text { assumed }\end{array}$} & \multirow[b]{2}{*}{.020} & \multirow[b]{2}{*}{.889} & \multirow[b]{2}{*}{-3.379} & \multirow[b]{2}{*}{143} & \multirow[b]{2}{*}{.001} & \multirow[b]{2}{*}{-.4580} & \multirow[b]{2}{*}{.1356} & Lower & Upper \\
\hline & & & & & & & & -.7260 & -.1901 \\
\hline $\begin{array}{l}\text { Equal variances } \\
\text { not assumed }\end{array}$ & & & -3.285 & 74.361 & .002 & -.4580 & .1394 & -.7358 & -.1803 \\
\hline
\end{tabular}

Table 6. T-test for Instructor Overall Satisfaction (OS)

Group Statistics

\begin{tabular}{l|ccccc}
\hline & EducationGroup & $\mathbf{N}$ & Mean & Std. Deviation & Std. Error Mean \\
\hline \multirow{2}{*}{ InstructorOS } & Pre & 43 & 3.186 & .6988 & .1066 \\
& Post & 102 & 3.353 & .6986 & .0692 \\
\hline
\end{tabular}

Table 7. Independent Samples Test for Instructor Overall Satisfaction

\begin{tabular}{|c|c|c|c|c|c|c|c|c|c|}
\hline \multirow[b]{2}{*}{ InstructorOS } & \multicolumn{2}{|c|}{$\begin{array}{c}\text { Levene's Test for } \\
\text { Equality of Variances }\end{array}$} & \multicolumn{7}{|c|}{ t-test for Equality of Means } \\
\hline & $\mathbf{F}$ & Sig. & $\mathbf{t}$ & df & Sig. (2-tail) & $\begin{array}{c}\text { Mean } \\
\text { Difference }\end{array}$ & $\begin{array}{l}\text { Std. Error } \\
\text { Difference }\end{array}$ & $\begin{array}{r}95 \% \mathrm{C} \\
\text { Inter } \\
\text { Diff }\end{array}$ & $\begin{array}{l}\text { fidence } \\
\text { of the } \\
\text { ence }\end{array}$ \\
\hline \multirow{2}{*}{$\begin{array}{l}\text { Equal variances } \\
\text { assumed }\end{array}$} & & & & & & & & Lower & Upper \\
\hline & .886 & .348 & .886 & .348 & -1.314 & 143 & .191 & -.4180 & .0842 \\
\hline $\begin{array}{l}\text { Equal variances } \\
\text { not assumed }\end{array}$ & & & & & -1.314 & 79.012 & .193 & -.4198 & .0860 \\
\hline
\end{tabular}

Result: $p>0.05$ which is not significant

Table 8. T-test for Environment Overall Satisfaction (OS)

\begin{tabular}{l|ccccc}
\hline Group Statistics & EducationGroup & N & Mean & Std. Deviation & Std. Error Mean \\
\hline \multirow{2}{*}{ EnvironmentOS } & Pre & 43 & 2.651 & 1.0439 & .1592 \\
& Post & 102 & 3.147 & .8605 & .0852 \\
\hline
\end{tabular}


Table 9. Independent Samples Test for Environment Overall Satisfaction

\begin{tabular}{|c|c|c|c|c|c|c|c|c|c|}
\hline \multirow[b]{2}{*}{ EnvironmentOS } & \multicolumn{2}{|c|}{$\begin{array}{c}\text { Levene's Test for } \\
\text { Equality of Variances }\end{array}$} & \multicolumn{7}{|c|}{ t-test for Equality of Means } \\
\hline & $\mathbf{F}$ & Sig. & $\mathbf{t}$ & df & Sig. (2-tail) & $\begin{array}{c}\text { Mean } \\
\text { Difference }\end{array}$ & $\begin{array}{l}\text { Std. Error } \\
\text { Difference }\end{array}$ & $\begin{array}{r}95 \% \mathrm{C} \\
\text { Interv } \\
\text { Diff }\end{array}$ & $\begin{array}{l}\text { fidence } \\
\text { of the } \\
\text { ence }\end{array}$ \\
\hline \multirow{2}{*}{$\begin{array}{l}\text { Equal variances } \\
\text { assumed }\end{array}$} & & & & & & & & Lower & Upper \\
\hline & 4.743 & .031 & -2.970 & 143 & .003 & -.4959 & .1669 & -.8259 & -.1659 \\
\hline $\begin{array}{l}\text { Equal variances } \\
\text { not assumed }\end{array}$ & & & -2.746 & 67.218 & .008 & -.4959 & .1806 & -.8563 & -.1355 \\
\hline
\end{tabular}

Result: $p<0.05$ which is significant

Analysis 2: For this analysis the four levels of student responses were further categorized into two groups:

$$
\begin{aligned}
& 1=\text { Not at all satisfied } \\
& 2=\text { Dissatisfied } \\
& 3=\text { Satisfied } \\
& 4=\text { Extremely satisfied }
\end{aligned}
$$

Students' responses 1 and 2 were grouped into the "Not satisfied" category and student responses 3 and 4 were grouped in the "Satisfied" category (Table 10).

Crosstab

Table 10. Chi-Square for Course Overall Satisfaction (OS)

\section{Count}

\begin{tabular}{|c|c|c|c|c|c|}
\hline & Value & df & Asymp. Sig. (2-sided) & Exact Sig. (2-sided) & Exact Sig. (1-sided) \\
\hline Pearson Chi-Square & $5.439^{\mathrm{a}}$ & 1 & .020 & \multirow{6}{*}{.034} & \multirow{6}{*}{.020} \\
\hline Continuity Correction ${ }^{\mathrm{b}}$ & 4.404 & 1 & .036 & & \\
\hline Likelihood Ratio & 5.104 & 1 & .024 & & \\
\hline Fisher's Exact Test & & & & & \\
\hline Linear-by-Linear Association & 5.402 & 1 & .020 & & \\
\hline $\mathrm{N}$ of Valid Cases & 145 & & & & \\
\hline
\end{tabular}

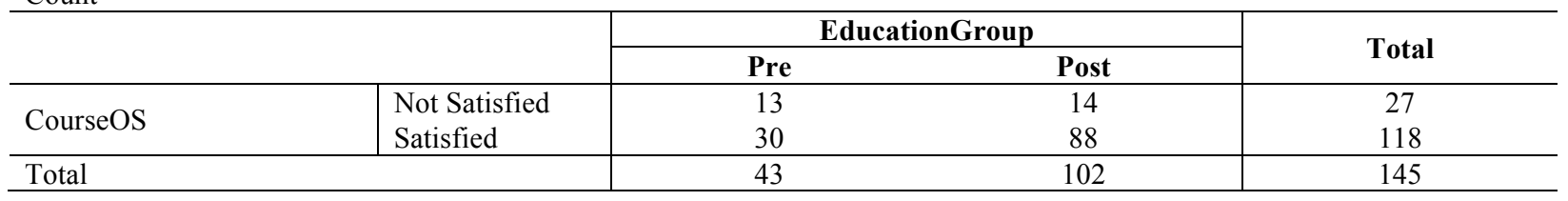

Chi-Square Tests for Course Overall Satisfaction are outlined below (Table 11).

Table 11. Chi-Square Tests for Course Overall Satisfaction

a. 0 cells $(.0 \%)$ have expected count less than 5 . The minimum expected count is 8.01 .

b. Computed only for a $2 \times 2$ table

Result: $p<0.05$ which is significant

Chi-Square for Instructor Overall Satisfaction (OS is listed below) (Table 12). 
Table 12. Chi-Square for Instructor Overall Satisfaction

\begin{tabular}{|c|c|c|c|c|}
\hline \multicolumn{5}{|l|}{ Crosstab } \\
\hline \multicolumn{5}{|l|}{ Count } \\
\hline & & \multicolumn{2}{|c|}{ EducationGroup } & \multirow{2}{*}{ Total } \\
\hline & & Pre & Post & \\
\hline InstructorOS & $\begin{array}{c}\text { Not Satisfied } \\
\text { Satisfied }\end{array}$ & $\begin{array}{c}5 \\
38\end{array}$ & $\begin{array}{c}9 \\
93\end{array}$ & $\begin{array}{c}14 \\
131\end{array}$ \\
\hline Total & & 43 & 102 & 145 \\
\hline
\end{tabular}

Chi-Square Tests for Instructor Overall Satisfaction are outlined below (Table 13).

Table 13. Chi-Square Tests for Instructor Overall Satisfaction

\begin{tabular}{|c|c|c|c|c|c|}
\hline & Value & df & Asymp. Sig. (2-sided) & Exact Sig. (2-sided) & Exact Sig. (1-sided) \\
\hline Pearson Chi-Square & $.273^{\mathrm{a}}$ & 1 & .602 & & \\
\hline Continuity Correction $^{\mathrm{b}}$ & .046 & 1 & .830 & & \\
\hline Likelihood Ratio & .264 & 1 & .607 & & \\
\hline Fisher's Exact Test & & & & .759 & .403 \\
\hline Linear-by-Linear Association & .271 & 1 & .603 & & \\
\hline $\mathrm{N}$ of Valid Cases & 145 & & & & \\
\hline
\end{tabular}

a. 1 cells $(25.0 \%)$ have expected count less than 5 . The minimum expected count is 4.15 .

b. Computed only for a $2 \times 2$ table

Result: $p>0.05$ which is not significant

Chi-Square for Environment Overall Satisfaction (OS) is listed below (Table 14).

Table 14. Chi-Square for Environment Overall Satisfaction (OS)

\begin{tabular}{|c|c|c|c|c|}
\hline \multicolumn{5}{|l|}{ Crosstab } \\
\hline \multicolumn{5}{|l|}{ Count } \\
\hline & & \multicolumn{2}{|c|}{ EducationGroup } & \multirow{2}{*}{ Total } \\
\hline & & Pre & Post & \\
\hline \multirow{2}{*}{ EnvironmentOS } & Not Satisfied & 15 & 17 & 32 \\
\hline & Satisfied & 28 & 85 & 113 \\
\hline \multicolumn{2}{|l|}{ Total } & 43 & 102 & 145 \\
\hline
\end{tabular}

Chi-Square Tests for Environment Overall Satisfaction are identified below (Table 15).

Table 15. Chi-Square Tests for Environment Overall Satisfaction

\begin{tabular}{|c|c|c|c|c|c|}
\hline & Value & df & $\begin{array}{c}\text { Asymp. Sig. (2- } \\
\text { sided) }\end{array}$ & $\begin{array}{l}\text { Exact Sig. } \\
\text { (2-sided) }\end{array}$ & $\begin{array}{l}\text { Exact Sig. } \\
\text { (1-sided) }\end{array}$ \\
\hline Pearson Chi-Square & $5.837^{\mathrm{a}}$ & 1 & .016 & \multirow{6}{*}{.027} & \multirow{6}{*}{.016} \\
\hline Continuity Correction $^{\mathrm{b}}$ & 4.825 & 1 & .028 & & \\
\hline Likelihood Ratio & 5.523 & 1 & .019 & & \\
\hline Fisher's Exact Test & & & & & \\
\hline Linear-by-Linear Association & 5.796 & 1 & .016 & & \\
\hline $\mathrm{N}$ of Valid Cases & 145 & & & & \\
\hline
\end{tabular}

\section{DATA ANALYSIS SUMMARY}

The t-test and Chi square test were used to assess the correlation between the student evaluations prior to and following implementation of inter-professional collaboration. Levene's tests for equality of variances were conducted to assess the internal consistency of the measurement scales and all data. Results indicated that the overall student satisfaction rating with the pathophysiology online course was significant at the $p<0.05$ following the implementation of the inter-professional teaching methodology. Results also indicated the overall student satisfaction rating with the instructor teaching the course did not significantly increase following the implementation 
of the inter-professional model. This may be because prior to the implementation of the inter-professional model, the nursing faculty were teaching the course singularly and also continued to teach with an inter-professional partner following the implementation of the inter-professional teaching methodology. Lastly, results indicated that the overall student satisfaction rating with the pathophysiology online environment was significant at the $p<0.05$ following the implementation of the inter-professional teaching methodology.

Student enrollment prior to and after implementation of collaborative teaching was calculated. Prior to implementation of collaborative teaching, the total enrollment in two courses of pathophysiology was 194 . After the institution of collaborative teaching, the total student enrollment in four courses was 605 . These large numbers reflected a statistically significant increase in total student enrollment of $311 \%$.

\section{IMPLICATIONS FOR NURSING PRACTICE}

Today, the complex healthcare delivery system necessitates a shift from traditional education to an interprofessional collaborative teaching model that generates knowledge from interaction with a variety of educators from a variety of disciplines (Hean, Craddock, \& Hammick, 2012). Successful graduates are those able to integrate a variety of professional and inter-professional approaches to healthcare delivery (Carpenter \& Dickinson, 2008). Pollard's (2008) stance is that inter-professional education should be offered by universities to students within the healthcare disciplines. The challenge is not to merge disciplines together, but rather to integrate perspectives from complementing disciplines with the common goal of improved patient outcomes (Coster et al., 2007). Achieving improved patient outcomes necessitates that healthcare providers respect and encourage the skill set and contributions of all colleagues across multiple disciplines. Upon graduation, nursing students trained with an interprofessional approach are better prepared to support colleagues within their working environments and develop collegial relationships with all members of the healthcare team. Furthermore, the inter-professional educational model nurtures the belief that colleagues are not expected to assume responsibilities outside their existing level of knowledge, skill-set and experience. Instead, a reciprocal mutual relationship is formed which fosters accountability within the respective professions. The overarching aim of inter-professional education is to prepare graduates who possess the knowledge, skill-set and characteristics required to collaborate inter-professionally within practice settings while actively contributing to positive patient outcomes (Carpenter \& Dickinson 2008).

A second nursing implication relates to the current disciplinary boundaries within healthcare (Beattie, 1995) and the monopoly each discipline has over a particular knowledge set. The use of IPE within the academic setting will foster collegial relationships and a shared vision for the gamut of stakeholders in future clinical environments that students will engage. Nursing curricula is needed which fosters both an inter-professional learning of shared knowledge between healthcare disciplines and the discipline-specific learning essential for each professional practice. Within the workforce, nurses will not function independently and will interact on a daily basis with multiple disciplines while caring for their patients. Because professional education (nursing curriculum) serves as the socialization into the values and characteristics of a chosen profession (nursing), which interacts daily with non-nursing professionals, the inclusion of inter-professional learning is essential. Through utilization of IPE, the student is gaining knowledge specific to their profession while gaining a greater understanding of and respect for other professions. Hean, Craddock and Hammick (2009) postulate a successful inter-professional relationship exists when stakeholders have the ability to give up a mono-disciplinary view of the patient and integrate the professional knowledge of all the members of the healthcare team.

\section{AUTHOR INFORMATION}

Dr. Crouch (contact author), graduated from Wright State University with a BSN and MSN in nursing. She earned a doctorate in education from Florida Atlantic University in 1999. She is an Advanced Registered Nurse Practitioner and board certified in Psychiatric Nursing. Dr. Crouch has publications in Maternal-Child Nursing, Nursing Education, Nursing Leadership, and the Acute Care Environment. Dr. Crouch has received recognition for her work through national and international presentations and consultations. She also has publications in the Virginia Henderson International Library, in affiliation with Sigma Theta Tau International. Email: scrouch@,chamberlain.edu 
Dr. Fillmore graduated from Madonna University with a BSN and University of Phoenix with an MSN. She earned a Doctorate from Touro University in Nursing Practice. She has worked in a variety of outpatient and inpatient settings in Adult Health. She has been a nursing educator in both academia and clinical settings for more than fifteen years. She has been a nursing education administrator for the last eleven years and currently is the Dean of Faculty at Chamberlain College of Nursing. She has focused on innovative teaching strategies, interprofessional educational models, and in areas of continuous quality improvement and safety. Email: 1fillmore@chamberlain.edu

Dr. Fly graduated from University of Central Oklahoma with a BSN in 1984, a MPA from Golden Gate University in 1987, a MSN from Abilene Christian University in 1994, and a doctorate in philosophy of nursing from Oklahoma University Health Sciences Center in 2013. Dr. Fly has been a nurse educator for 28 years and has academia experience at all levels of nursing practice (ADN, BSN, RN-BSN, and MSN). During the last ten years, Dr. Fly has served in numerous nursing education administration positions and currently is the Dean of Prelicensure Online at Chamberlain College of Nursing. Email: 1fly@chamberlain.edu

Dr. Ukot has been in healthcare since 1994, and holds a Bachelor of Science degree in Nursing, a Bachelor of Science degree in Management Information Technology, a Master's of Science in Nursing, an MBA in Healthcare Management, and a Doctor of Nursing Practice from Carlow University. Her clinical area of expertise is in Informatics, Adult Health, Emergency Nursing, Administration, Informatics, and Neurosciences. She has been a nurse educator in both online and on campus settings for several years. Dr. Ukot has presented both nationally and internationally on nursing education. Email: eukot@chamberlain.edu

\section{REFERENCES}

American Association of Colleges of Nursing. (2006). The essentials of doctoral education in advanced nursing practice. Washington, DC: Author. Retrieved from http://www.aacn.nche.edu/dnp/pdf/essentials.pdf

American Association of Colleges of Nursing. (2008). The essentials of baccalaureate education for professional nursing practice. Washington, DC: Author. Retrieved from http://www.aacn.nche.edu/education/pdf/BaccEssentials08.pdf

American Association of Colleges of Nursing. (2011). The essentials of a master's education in nursing. Washington, DC: Author. Retrieved from http://www.aacn.nche.edu/Education/pdf/DraftMastEssentials.pdf

Alberto, J., \& Herth, K. (2009, March 31). Inter-professional collaboration within faculty roles: Teaching, service, and research. Online Journal of Issues in Nursing, 14(2).

Atherton, J. S. (2011). Teaching and Learning. Forms of Assessment [On-line: UK] http://www.learningandteaching.info/teaching/assess_form.html.

Barr, H., Koppel, I., Reeves, S., Hammick, M., \& Freeth, D. (2005). Effective inter-professional education: Argument, assumption and evidence. Oxford, London: Blackwell Publishing.

Beattie, A. (1995). War and peace among the health tribes. Inter-professional Relations in Health Care, 11-30.

Brandon, A.F., \& All, A.C. (2010). Constructivism theory analysis and application to curricula. Nursing Education Perspective, 31(2), $89-92$.

Carpenter, J. \& Dickinson, H. (2008). Inter-professional education and training. Bristol: The Policy Press.

Cooper, H., Carlisle, C., Watkins, C., \& Gibbs, T. (2001). Developing an evidence base for interdisciplinary learning. Journal of Advance Nursing, 35(2), 228-237.

Coster, S., d'Avray, L., Dawson, P., Dickinson, C., Gill, E., Gordon, F., ... \& Steven, A. (2007). Piloting interprofessional education: Four English case studies.

Devry (2013). About us: Purpose, vision and values. Retrieved from http://www.devryinc.com/about-us.jsp

Dyer, J. A. (2003, July/August). Multidisciplinary, interdisciplinary, and transdisciplinary, educational models and nursing education. Nursing Education Perspectives, 24(4), 186-188.

Hean, S., Craddock, D., \& Hammick, M. (2012). Theoretical insights into inter-professional education. Medical Teacher, 34(2), 158-160.

Hean, S., Craddock, D., \& O'Halloran, C. (2009). Learning theories and inter-professional education: A user's guide. Learning in Health and Social Care, 8(4), 250-262. 
Pollard, K. C. (2008). Non-formal learning and inter-professional collaboration in health and social care: The influence of the quality of staff interaction on student learning about collaborative behavior in practice placements. Learning in Health and Social Care, 7(1), 12-26.

Silver, I. L., \& Leslie, K. (2009). Faculty development for continuing inter-professional education and collaborative practice. Journal of Continuing Education in the Health Professions, 29(3), 172-177.

Vygotsky, L.S. (1978). Mind in society: The development of higher psychological processes. Cambridge, MA: Harvard University Press.

World Health Organization (WHO). (2010). Framework for action on inter-professional education and collaborative practice. Geneva: World Health Organization. 